\title{
Narrative Style of Time of Habiburrahman El Shirazy in Building the Bidadari Bermata Bening Novel
}

\author{
${ }^{1}$ Noermanzah*, ${ }^{2}$ Syafryadin, ${ }^{3}$ Ira Komala Sari, ${ }^{4}$ Juwati, ${ }^{5}$ Feny Martina
}

\begin{abstract}
This study aims to describe the narrative style of time of Habiburrahman El Shirazy's in developing the Bidadari Bermata Bening novel. The research method used is the narrative method. Data collection techniques using documentation techniques. Data analysis techniques with steps: compiling a series of events in the novel, determining the time of events in the novel and the actual time of events, and determining the type of time contained in the novel. Test the validity of the data using member checking, bending, and validation of literary experts. The results showed that the narrative style of time by Habiburrahman El Shirazy in constructing the Bidadari Bermata Bening novel consists of: (1) the actual duration of the story is 59 years starting from the introduction of Ayna's parents, until Ayna lived happily in Amman with her husband, Afif. (2) Order of the story in the novel's text is a 10-year story of the event starting from the atmosphere of Ayna in Kanzul Ulum Islamic Boarding School, Magelang, Ayna who was still in high school class, then made a flashback or flashback, namely telling the present and past when the death event Ayna's parents, and the Ayna parents meeting in Jordan, then the story ends with Ayna's happiness in Amman with her husband, Afif. Then, (3) frequency in the form of repetitive frequency is more dominant followed by singular, multiple-singular, and iterative frequencies. While the events that often arise are the events of Ayna's adolescence, namely the story of Ayna who received the National Examination score, Ayna who could not watch the Wayang Kulit performance, the love story of Ayna and Afif, the event of Ayna's adult life which is the story of Ayna's life with Yoyok, the difficulties of Ayna's life after getting divorced from Yoyok, and Ayna's success.
\end{abstract}

Keywords: narrative style of time, duration, order, frequency, novel

\section{Introduction}

Literary works in the form of narrative prose is a novel. The novel comes as a narrative prose that tries to tell a series of events from an event that reflects the reality of life at the time the novel was written (Wellek \& Warren, 1976; Sulaeman, 2020). The series of events presented in the novel teaches the reader about life's journey at a certain time, even though there is a fictional element. The series of events in a novel is composed by

\footnotetext{
${ }^{1}$ University of Bengkulu, Bengkulu City, Indonesia

${ }^{2}$ University of Bengkulu, Bengkulu City, Indonesia

${ }^{3}$ STKIP PGRI Lubuklinggau, Lubuklinggau City, Indonesia

${ }^{4}$ STKIP PGRI Lubuklinggau, Lubuklinggau City, Indonesia

${ }^{5}$ Institute Agama Islam Negeri Bengkulu, Bengkulu City, Indonesia
} 
the author with all the elements that make up the narrative writing. This is consistent with the opinion of Mihardja (2012), that the novel is a written prose literary work and is narrative in nature. Novel as a work of fiction prose contains elements of the world of life, the imaginative world, which is built through various intrinsic elements such as themes, plots, figures and characterizations, settings, perspectives, and messages. Thahar (2008) argues that in a novel there is often a fairly clear place or setting, so that event after event is interrelated and experienced by the main character and other characters involved in the story.

Tell a literary work, both novels and other literary works must be interesting and contain aesthetic or aesthetic value. The author is freed more in expressing the creativity of the choice of words and languages that will be used in writing a literary work both fictional and nonfiction with a series of events starting from recognition, conflict, climax, and resolution (Noermanzah, 2017). The language game in the narrative is the same as the language game of an orator who utilizes the mastery of rhetoric, especially in compiling ethos, pathos, and logos so that the reader can be persuaded and follow the writer's thoughts (Noermanzah et al., 2019). Pratista (in Kustanto, 2015) argues that the narrative is a series of events that are interconnected with each other formed by cause and effect that occur based on the place and time sequence in a story. A narrative certainly has a logically intertwined relationship that is connected by the subject in a story so as to produce logical thinking that is able to give effect to the reader.

Herman \& Vervaeck (2005) explain that narratives as semiotic representations and a series of events that are meaningfully related in a temporal and causal way. Barry (2002) explains more specifically that narrative as a story told by presenting a series of events that are edited, compiled, packaged, and presented chronologically. Some of these opinions have the same concept that the narrative is a story that consists of a series of events related to one another then edited, arranged, and packaged in the form of text that is presented chronologically.

The narrative was also put forward by Herman (2007) as the narrator's thought or cognitive expression in the form of a discourse that reveals stories in the form of events or sequences of events inspired by information in the form of problem solving, conflict, interpersonal relationships, human experience, and temporary existence. which has a social function. Thus, narrative is a work of fiction that tells a series of events that are causal and temporal in a certain time that aims as a semiotic representation.

A sequence of events intertwined in the story on the basis of relationships that contain mutual causes and effects. Events in the narrative sense are actions and events, both of which are changes in circumstances (Hartono, 2005). An action is a change in circumstances brought about by the presence of an agent or a change in circumstances affecting a patient. If the action is significant-plot, the agent or patient is called a character (Chatman, 1980). Then, the events in the story are arranged in chronological order, not in discourse timeline.

Nurgiyantoro (2012) argues that language expression in narrative style is all forms of speech spoken through written or spoken language in the form of one event to another that is continuous. In this case the author can tell a story or story through a description of the place or setting of the story, characters involved in the story, relationships between characters, problems or conflicts that occur in the story, and others. This form of narration can also tell an event briefly. The author prefers events and actions, conflicts, or other interesting things from the character's life journey told.

The effectiveness and beauty of a story in a novel depends on the ability and skill of the author himself in interweaving an event that occurs in a story. The author must be able to combine various kinds of behavior or 
actions, and actions that become a unity of events, so that the reader can understand and feel the purpose and meaning of the story told in the novel. Zakir (2014) explains that the author's power is invisible to the text of his novel. In this case the text is manifested as a depiction of a life that can be seen from the author's perspective. The description of the character's character, place or setting of the story, and the event becomes a subject for an author.

One novel that is very inspiring to be analyzed is a novel by Habiburrahman El Shirazy entitled Bidadari Bermata Bening. The novel Bidadari Bermata Bening has a very enticing story. The novel Bidadari Bermata Bening tells the story of the loyalty of love and sincerity to achieve ideals. This novel describes the world of boarding school. Educational values in boarding school are conveyed in beautiful literary language. This novel can motivate students in general, the younger generation to achieve success through hard work, perseverance, and humility.

The advantages of Habiburrahman El Shirazy's in Bidadari Bermata Bening novel are always related to the meanings of life that are able to inspire the soul for its readers. Every story written by Habiburrahman El Shirazy always provides its readers with wisdom. The main character female named Ayna in this novel has a standardized character in real life. Ayna in this novel is to have a nature that is always doing good, has a patient nature, always remembers Allah, but a Ayna is also not immune from deficiencies in dealing with various problems of life. This novel is also able to provide positive energy to achieve a dream. Another advantage of the Bening-eyed Bidadari novel is that it has many advantages including the style of language that the author makes that is easily understood by the reader, lightweight but very weighty. The message or message delivered in this novel is easily absorbed, the plot or plot of the story is always changing so that it can play the emotions of its readers.

Some of the results of research on the theory of this narrative are research conducted by Zakir (2014) with the title Research Author and Authorities: Anwar Ridhawan's Current Thought and Narrative Style. The results of his research show that the most positive thing to realize a high literary work is the author's own power. Anwar Ridhwan as the writer of the novel shows a very appropriate thought in the novel Penyemberang Sepadan. The right thinking is shown with the support of Anwar Ridhwan's narrative style in the novel Penyemberang Sepadan which is built by a system of values through a very special logic thinking text.

This narrative research was also carried out by Didipu (2018:) with the research title Narrative Structure of Osakat Anak Asmat Novel by Ani Sekarningsih (Perspective of Narartology Gerard Genette). The results showed that the novel Osakat Anak Asmat by Ani Sekarningsih contained four narrative structures, the first being the Osakat Anak Asmat novel by Ani Sekarningsih arranged with an acronymical narrative sequence pattern, meaning that there were parallels between the time of the telling. Second, there are scenes and pauses in a narrative duration movement used by the author. Third, there are every story of events that occur in the novel only told by the author once too. Fourth, there is a point of view, that is, the narrator outside the story means that the narrator knows more about what is known by one or several characters in the story.

From some of the results of previous studies, it has been shown that he has not yet studied the narrative style, especially the narrative style of time. The narrative style of this time relates to how an author's thoughts to form a novel that impresses the reader. Thahar (2008: 38) argues that in every work written by an author, it must have its own style, the style can be displayed by the author through the plot or plot, setting, characterizations and themes written in his work. Zakir (2014: 73) suggests that the author's authority over his text in shaping 
narrative thought and style can be seen in the formation of ruling thought through time, character, setting, events, and the angle of author's love. This is in accordance with the opinion of Eriyanto (2017) the most important aspects in the narrative are 1) time related to duration, order, and frequency; 2) space relating to the setting or character; and 3) narrator related to the author's position.

According to Gamble \& Yates (2002), time in fiction is identified into three parts, namely order, duration, and frequency. Each part of the time has a difference, both in terms of story, plot and text presented to the public. Duration according to Gamble \& Yates (2002) is a relation between the length of time an action takes place in the actual time and the amount given to the action in the text. For example, wearing a pair of socks can last for three or four pages in a novel. Instead a few years in events can be shortened to a few sentences.

Order is a sequence of events in a clear chronology in a story (Herman \& Vervaeck, 2005). Herman (2007) describes order as presenting the sequence of events in important texts because the temporal experience of narrative and sequence aims to anticipate the reader about what will happen next in the story and what will happen at the end of the story. Then, the frequency associated with repetition of events and if the event is repeated several times in the narrative will affect the interpretation of the reader (Herman, 2007). Repetition involves more than one event at the level of a single story discourse, while literacy involves a single telling of several events.

Eriyanto (2013) also explains the frequency related to the number of times that the same event is displayed, both in the story, plot, and text. In one story, the frequency category has been confirmed to be absent because of real-time events, certainly only once, and may not be repeated. However, in a plot or text, an event might be presented several times. Next Herman \& Vervaeck (2005), explains that frequency refers to the relationship between the amount of time an event that occurs in a story and some time events that occur in a narrative. This relationship is often (singulative), more frequent (literacy), and less often or occasionally at the level of the story (repitition).

In general, Bidadari Bermata Bening novel tells the thoughts and narrative style of time in the context of the author's power over the text. The series of events in the Bidadari Bermata Bening novel are built with a narrative style of time that is free by Habiburrahman El Shirazy. This can be seen from the actual time sequence of the story and the time of the story in the text of the novel, which is used by Habiburrahman El Shirazy in the Bidadari Bermata Bening novel thus delivering his thoughts strongly and impressively to the reader. The narrative style of storytelling used by Habiburrahman El Shirazy in the Bidadari Bermata Bening novel is like moving the story with a timeline of stories that are so interesting by using a mixed plot, place or story setting that occurs everywhere so that it forms a character character involved in this novel has a different character. For this reason, in this case the narrative style of Habiburrahman El Shirazy's time in the Bidadari Bermata Bening novel is very important to build a story that is interesting and beautiful for the reader.

Based on the background description of the problem in this study, the researcher focused the research problem on the narrative style of Habiburrahman El Shirazy's time in developing the Bidadari Bermata Bening novel. The research subfocus is duration, order and frequency. Theoretically, this research is useful in developing the theory of narrative style, especially the narrative style of time from Indonesian writers, Habiburrahman El Shirazy in his novel, Bidadari Bermata Bening. 


\section{Methods}

This research uses a narrative method. The narrative method is one of the qualitative methods that attempts to interpret a series of events in a story written by the author or tell the author's history in his life especially in this case the life story in the novel. In this study, it will be explained how the time narrative style used by Habiburrahman El Shirazy in his novel entitled Bidadari Bermata Bening as research data. The data source in this study is primary data, namely the Bidadari Bermata Bening by Habiburrahman El Shirazy, published by the Republic, the city of Jakarta, and the number of pages 336 in printed form (Shirazy, 2017).

The data collection technique was in the form of a documentation technique in the form of a Bidadari Bermata Bening novel by Habiburrahman El Shirazy in the printed version. Data analysis techniques by analyzing events from time to time until ending, constructing events based on flow and time in the actual text and flow, inferring the time of events in terms of duration, order, and frequency (Creswell, 2007). Then, test the validity of the data using member checking, increased bending, and validation from literary experts.

\section{Results and Discussion}

\section{Results}

The research carried out focused on the narrative style of Habiburrahman El Shirazy's time in developing the Bidadari Bermata Bening novel. In the Bidadari Bermata Bening novel by Habiburrahman El Shirazy about time is divided into three types, as follows.

\section{a. Duration}

The duration in the novel Bidadari Bermata Bening by Habiburrahman El Shirazy with the actual story time is 59 years. Habiburrahman El Shirasy's in the Bidadari Bermata Bening novel tells the story of her parents' introductions which took place in the city of Amman, Jordan. The death of Ayna's father in Stockholm, Sweden. At that time Ayna was still in her mother's womb. The death of Ayna's mother when Ayna was still in grade 1 high school at the Kanzul Ulum Islamic Boarding School, Magelang.

The events of childhood Ayna, elementary school, and junior high school, Ayna in Kaliwenang Village. The events of Ayna's adolescence are still high school class 3 which will soon receive the National Examination results, and Ayna's adulthood after graduating from high school Ayna is married, studying, and working. In adulthood, Ayna traveled a life full of twists and turns, Ayna married a young man she did not love, namely Yoyok. A year of marriage, Ayna and Yoyok separated. Ayna migrated to the city of Bandung and Bogor, in this overseas city Ayna experienced many difficulties of life that is homeless and starving. In the Bogor City, Ayna can achieve happiness and success, that is, being able to work in a well-known office, study, and open her own business, which is a highly developed Barokah Bread.

\section{b. Order}

Order in the Bidadari Bermata Bening novel by Habiburrahman El Shirazy is a sequence of stories in the text told for 10 years. The order of events in the Bidadari Bermata Bening novel by Habiburrahman El Shirazy is not written chronologically or in sequence. Habiburrahman El Shirazy uses a mixed groove. Bidadari Bermata Bening novel starts from the atmosphere of Ayna at Kanzul Ulum Islamic Boarding School, Magelang. Ayna, who is still in Senior High School class 3 which will soon receive the results of graduation. The Bidadari 
Bermata Bening novel then makes a flashback that tells the present and the past when the death of Ayna's parents and Ayna's parents' meeting in Jordan.

Then the story goes to the moment when Ayna was a teenager about Ayna's romance, which was full of obstacles and sadness, Ayna's adult life. It was during this adult period that Ayna experienced many life difficulties such as household problems with Yoyok, a man who was not loved, so over a year of marriage Ayna and Yoyok finally divorced. Ayna migrated to another city by eating rice left over from other people because of hunger, she had no money and no work, no place to stay. However, thanks to patience and never despair Ayna can achieve a success in the city of Bogor. Ayna's success was being able to study and work in one of the most well-known offices in Bogor and build her own business, the highly developed Barokah Bakery. Then, the story ends with Ayna's meeting with her brother in Amman and Ayna's meeting with a High School friend named Neneng, then the happiness of Ayna and Afif who have become a married couple living in Amman.

\section{c. Frequency}

The frequency in the Bidadari Bermata Bening novel by Habiburrahman El Shirazy starting from the story of Ayna's adolescence is still in 3rd grade high school at Kanzul Ulum Islamic Boarding School, Magelang, which received the highest National Examination score. The death of Ayna's father in Stockholm, Sweden. At that time Ayna was still in her mother's womb. Introduction of his parents who happened in the city of Amman, Jordan. The death of Ayna's mother when Ayna was still in grade 1 high school at the Kanzul Ulum Islamic Boarding School, Magelang.

The events of Ayna's childhood, Ayna's elementary school, and junior high school in Kaliwenang Village. Then, the events of adulthood Ayna after graduating from high school high school then Ayna married, went to college, and worked. It was during this adult period that Ayna went through a journey of twisted lives, Ayna married a young man she did not love, namely Yoyok and a year of marriage Ayna and Yoyok separated. Ayna migrated to the city of people namely Bandung and Bogor, in this overseas city Ayna experienced many difficulties of life that is homeless and starving. In the Bogor City, Ayna can achieve happiness and success, that is, being able to work in a well-known office, study, and open her own business, the highly developed Barokah Bread. The events in this Bidadari Bermata Bening novel Habiburrahman El Shirazy use a mixed story line, telling past and present events or flashbacks.

The time related to the frequency in the Bidadari Bermata Bening novel by Habiburrahman El Shirazy, has 54 events in the novel with the frequency types presented more dominant using repetitive frequencies and there are also types of singular, multiple-singular, and iterative frequencies. Then, the frequency of events is based on the repetition of events that often appear in Bidadari Bermata Bening novels, namely: 1) Ayna's adolescent events that received the highest National Examination scores; 2) Ayna's teenage events who could not watch the Wayang Kulit performance, 3) Ayna's teenage events namely the love story of Ayna and Afif; and 4) Ayna's adult events are the story of Ayna's married life with Yoyok, the difficulties of Ayna's life after divorce from Yoyok, and Ayna's success.

\section{Discussion}

The narrative style of time compiled by Habiburrahman El Shirazy in the Bidadari Bermata Bening novel in the form of duration, order, and frequency has a uniqueness and complementarity between the three. 
This is consistent with the opinion of Eriyanto (2017); Gamble \& Yates (2002), one important aspect of narrative in building an interesting and beautiful novel is time in the form of duration, order, and frequency.

The duration contained in the Bidadari Bermata Bening novel by Habiburrahman El Shirazy in the actual story is 59 years and can be told in only 10 years in the text of the novel. This is consistent with the opinion of Eriyanto (2017) duration is the time of an event, which refers to the total time from the beginning to the end of the story, and the duration in an actual story can be months, years, and even hundreds of years depending on the event be told.

The order contained in the Bidadari Bermata Bening novel by Habiburrahman El Shirazy can be told in the text of the novel is 10 years. Habiburrahman El Shirazy tells of an event not written sequentially or chronologically, the Bidadari Bermata Bening novel tells the story of the present and the past or flashbacks. This is in accordance with the opinion Didipu (2018) order refers to the relationship between the sequence of events in the story and its arrangement in the story.

The frequency contained on Habiburrahman El Shirazy's Bidadari in the Bidadari Bermata Bening novel occurs as many as 54 events experienced by the characters involved in a story, with events that often occur, namely 1) Ayna's teenage event that gets the highest National Examination score twice in the story told in the quote (GNW 003, pages 9-16 and GNW 011, pages 59-71); 2) the events of Ayna's adolescence who could not watch the Wayang Kulit performance are told twice as told in quotations (GNW 009, pages 44-51 and GNW 024 pages 138-155); and 3) the events of Ayna's adolescence namely the love story of Ayna and Afif were told twice, namely in quotations (GNW 024 pages 138-155 and GNW 053, pages 323-331).

The frequency types presented are more dominant using repetitive frequencies and there are also types of singular, multiple-singular, and iterative frequencies. Singular frequency is a single discourse that tells a single story event. Multiple-singular frequency is a number of times the discourse to tell several events. Repetitive frequency is several times the discourse for the same story event. Then, the iterative frequency is one discourse for a few moments of the story (Todorov, 1985).

For example the frequency of repetitive events in adulthood Ayna, especially stories about Ayna's married life with Yoyok and the difficulties of Ayna's life after divorce from Yoyok and Ayna's success told in quotations (GNW 040, pages 246-266) and (GNW 046, page 289 -297). This is consistent with the opinion of Eriyanto (2017: 35) \& Herman \& Vervaeck (2005: 66-67), that frequency refers to several times an event occurs which is displayed in the story. Habiburrahman El Shirazy in constructing the Bidadari Bermata Bening novel is very skilled in presenting time in the Bidadari Bermata Bening novel in the form of duration, order, and frequency. This can be seen in the following figure 1.

Actual story time duration:

59 years old. The event of the introduction of Ayna's parents (in 1957) until Ayna lived happily in the city of Amman with her husband, Afif (2016).

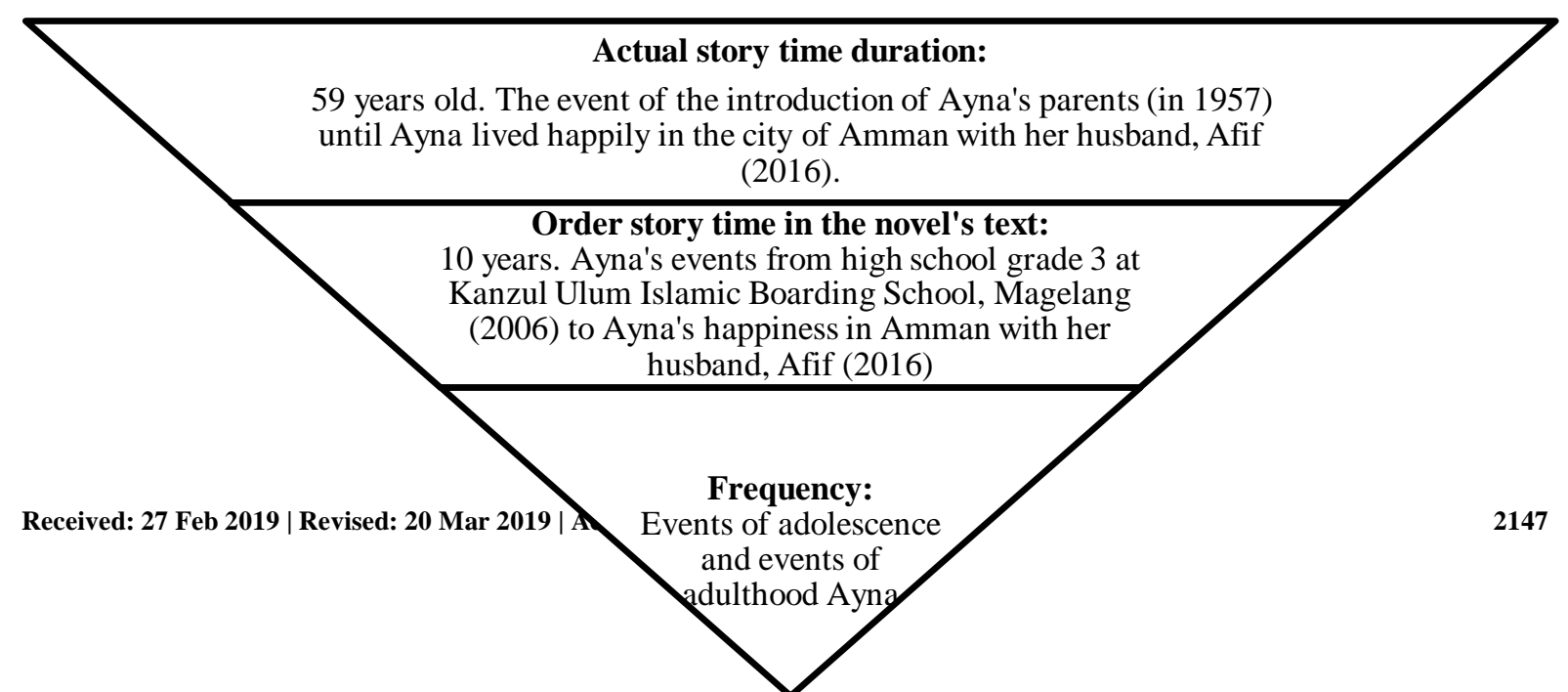




\section{Figure 1. Narrative Style of Time of Habiburrahman El Shirazy} in Building the Bidadari Bermata Bening Novel

Based on Figure 1 above, the narrative style of Habiburrahman El Shirazy's time in constructing the Bidadari Bermata Bening novel in the form of duration, order, and frequency was built so attractively. The interesting thing is that the actual duration of the story is 59 years. Yet when the story in the text can only be told by Habiburrahman El Shirazy for 10 years with a frequency of 54 events that occur then the repetition of events that often occur in the teenage events of Ayna namely Ayna gets the highest National Examination score, told twice, Ayna who cannot watch the Wayang Kulit show is told twice, Ayna and Afif's love story is told twice, and Ayna's adult life is Ayna's married life with Yoyok, the difficulties of Ayna's life after divorcing from Yoyok, and Ayna's success is told twice. Habiburrahman El Shirazy makes the story events in the novel not sequential or chronological using a mixed flow or flashback, but leads to a happy ending for the main character and for the reader.

The novel is told from the atmosphere at the Kanzul Ulum Islamic Boarding School, Magelang, Ayna who is still sitting in the 3rd grade high school who will soon receive the results of graduation, Ayna who is always consulted and demeaned by her classmate named Neneng. Then, Habiburrahman El Shirazy shifted the story of a flashback to tell the present and past when Ayna's parents were edited, and Ayna's parents' meeting in Jordan, and Ayna's childhood events when she was still in elementary school and junior high school in Kaliwenang Village. The events of the death of Ayna's parents, Ayna's father, are told on pages 17 to 22 . The incidents of introductions of Ayna's parents are told on pages 24 to 33 pages. The case of Ayna's mother's death is told on pages 100 to 110, and Ayna's childhood events when elementary school and junior high school are told on pages 111 to 118 .

The event shifts back to the present, namely the separation of the Ayna school which received the highest National Examination score and as a model student. After graduating from junior high school Ayna was proposed by Pak Kyai Yusuf widower 2, but the application was rejected by Pakde Ayna. Then, Afif a young man who was loved by Ayna who was late proposing to Ayna because Ayna had an arranged marriage with Yoyok. Ayna was arranged for marriage and married by Pakde and Budenya with Yoyok, a wealthy young man in the village of Purwodadi, a young man who was a source of evil and mischief in the village of Purwodadi and its surroundings.

A year of marriage to Yoyok finally Ayna managed to divorce from Yoyok. Yoyok was involved in a corruption case and one of the ways to release Yoyok was by means of Ayna marrying an old lawyer Bandot Brams. However, Yoyok and his in-laws' plan failed because they had been arrested by the police.

After the divorce, Ayna went to migrate to Bandung and Bogor, in this Bogor City Ayna suffered a lot. Ayna lives without hunger because she doesn't have a job, she is hungry until she eats leftover rice, and has no place to stay. Ayna met Rosidah's mother, a woman who helped Ayna from pickpockets. It was from Rosidah's mother that Ayna's life changed, Ayna got a job at the office of Rosidah's mother as Rosidah's assistant and 
lived with Rosidah's mother in a quite luxurious Bogor housing. Aside from being an assistant, Ayna also went to D-1 in Management. Ayna then opened her own business, which is a highly developed barokah bread, and Ayna could build a home for underprivileged street children.

Ayna, who was still alone after getting divorced from Yoyok, finally remarried because of a great love for a young man named Afif who had not met Ayna and Afif for several years. Ayna and Afif were reunited at a Bogor Hospital, Sardjito Hospital. Ayna and Afif decided to get married, after marriage Ayna and Afif lived in the city of Amman to continue their delayed ideals of studying in a foreign country, which is told in novels pages 138 to 155 . Ayna and Afif now live happily in the city of Amman because Ayna was pregnant with the first child of their marriage, Ayna and Afif hoped that the intimacy and happiness they felt would be recorded by Allah. as a form of worship.

The narrative style of time in the form of duration, order, frequency in the novel Bidadari Bermata Bening by Habiburrahman El Shirazy shows the general events that have occurred from the events of Ayna's adolescence who are still sitting in high school in grade 3 at Kanzul Ulum Islamic Boarding School. Events of Ayna's father's death, Ayna's parents' meeting, Ayna's mother's death, Ayna's childhood, and Ayna's adult life. Habiburrahman El Shirazy's narrative style of time that shows the duration, order, and frequency, is different from the results of relevant research conducted by Hartono (2005) which states that the duration consists of the duration of the scene, summary, pause, with chronological order the beginning of the story can also be the cause of subsequent events, although not directly and the most dominant frequency is the frequency of events that only occur once.

Based on the results of the analysis of the novel data there is also the actual duration of the story is 1 month while the story time used in the text of the novel is 1 day with events that occur are students who are doing breakfast breakfast activities and class 3 students who are still waiting for the National Examination results to come out. Then there is also, the events in the novel with the actual duration used by the author are 2 years with time to tell in the text is 1 day, with events in the Ayna boarding school and his friends discussing about their plans after graduation will continue to university mana, as well as stories about the quarrel between Ayna and Neneng, Neneng who insulted Ayna and her mother. The excerpt of the novel also tells of past events about the days when Ayna's mother was pregnant with Ayna and about the death of Ayna's father who died while completing her $\mathrm{PhD}$. The results of relavan research conducted by Aswidaningrum et al. (2017) are different, he uses the theory of Genette that each event has a relationship of repeating an event that is the same in the story with the time of its telling. Based on the analysis of the researchers the novel excerpt above Habiburrahman El Shirazy presents the story events in a sequence not telling about the present and past life or flashbacks.

There is also the actual duration of the story is 1 month, the time to tell stories in the novel for 3 days. Different relevant research results conducted by Hartono (2005) which states that the duration consists of the duration of the scene, summary, pause, with a chronological order the beginning of the story can also be the cause of subsequent events, although not directly and the most dominant frequency is the frequency of events that only occur once. Based on the results of data analysis, the event tells the story of Ayna's adolescence after the event graduated from school 1 month ago, then the event occurred in the text for 3 days Ayna was proposed by Mr. Kyai Yusuf. 
Based on the analysis of data in the novel excerpt above the author uses a mixed flow with one text capable of telling several events that occurred, for example events about Ayna's teenage years after graduating from high school and the times when she was still in high school at Kanzul Ulum Islamic Boarding School. The author also uses a text with events from several events, the first tells the story of Ayna who was matched by Pakdenya with Yoyok, then Afif came to Ayna's house with the intention of delivering the invitation of Kyai Yusuf's marriage to another woman, and on the other hand Afif also expressed another purpose for his arrival Ayna wants Ayna to be his wife, and the next event is about Ayna's time when she was still in school at the Islamic Boarding School who was willing to wash Afif's clothes at night and not follow her friends to watch the Wayang Kulit show to wash the clothes of the man that Ayna admired.

Then, in the novel Bidadari Bermata Bening there are also events with the actual duration of the story being 1 year, 4 months, while the story time in the novel's text is only 6 months. The author uses several texts to describe several events that occurred, namely the meeting between Ayna and her brother Ameera in the city of Amman, Ayna's meeting with Neneng a high school friend when at the Kanzul Ulum Islamic Boarding School who always insulted and demeaned Ayna now a female labor abroad in Amman, and happiness Ayna felt in the city of Amman with her beloved husband, Afif. This is consistent with the opinion raised by Eriyanto (2017) \& Barry (2002) that in a novel the sequence of events is usually not written chronologically with the intention of giving a curious effect to the reader or clarifying important events in the life of the main character.

Thus, Habiburrahman El Shirazy is very clever in presenting time in the Bidadari Bermata Bening novel by presenting duration, order, and frequency. The actual duration of the story 59 years with the event of the introduction of Ayna's parents in 1957 until Ayna lived happily in the city of Amman with her husband, Afif in 2016, can be told with a story order in the novel's text for 10 years. Then, the story in the novel becomes more interesting and not boring by repeating some of the frequency of events in adolescence and adulthood, the main character, Ayna. This frequency is in the form of repetition of the appearance of an event in the story by repeating the narration in the text, or the frequency with which events occur in the discourse. The frequency in the Bidadari Bermata Bening novels varies greatly, namely the frequency of singular, multiple-singular, repetitive, and iterative (Chatman, 1980; Hartono, 2005) and more dominant is the type of repetitive frequencies that are less frequent or occasionally appear at the level story. The four types of frequencies are able to provide a special attraction for the reader in performing flashbacks of events experienced by the characters.

\section{Conclusion}

Based on the results of research on the narrative style of time in the Bidadari Bermata Bening novel by Habiburrahman El Shirazy, it can be concluded that the following are:

1. The duration in the Bidadari Bermata Bening novel by Habiburrahman El Shirazy with the actual story time is 59 years, can be told in only 10 years in the text of the novel. Habiburrahman El Shirasy's in the Bidadari Bermata Bening novel tells the story of his parents' introduction in Amman, Jordan. The death of Ayna's father in Stockholm, Sweden, when Ayna was still in her mother's womb. The death of Ayna's mother when Ayna was still in high school in grade 1 at the Kanzul Ulum Islamic Boarding School, Magelang. The events of Ayna's childhood, elementary school, and Ayna junior high school in Kaliwenang Village. The events of adolescence Ayna is still a high school in grade 3 which will soon receive the results of the National Examination and after 
graduating high school, and the events of adulthood Ayna which ends with Ayna's happiness in the city of Amman with her husband, Afif.

2. Order in the Bidadari Bermata Bening novel by Habiburrahman El Shirazy the story in the novel's text is 10 years with a total of 336 pages. The order of events in Habiburrahman El Shirazy in the Bidadari Bermata Bening novel was not written chronologically or sequentially. Habiburrahman El Shirazy uses a mixed groove. The Bidadari Bermata Bening novel starts from the atmosphere of Ayna at the Kanzul Ulum Islamic Boarding School, Magelang, Ayna, who is still in high school in grade 3, will soon receive graduation results. The Bidadari Bermata Bening novel, then makes a flashback that tells the present and the past when the death of Ayna's parents, and the events of Ayna's parents' meeting in Jordan. Then the story ends on Ayna's happiness in Amman with her husband, Afif, as the ending of the story.

3. The frequency on Habiburrahman El Shirazy in the Bidadari Bermata Bening novel varies greatly, namely singular, multiple-singular, repetitive, and iterative frequencies. The more frequent frequencies are types of repetitive frequencies whose purpose is to invite the reader to recall important events from the main character. The events that often occur are the events of Ayna's teenage years, namely the story of Ayna who received the highest National Examination score, Ayna who could not watch the Wayang Kulit performance, Ayna and Afif's love story, and Ayna's adult life events about Ayna's life with Yoyok and the difficulties of Ayna's life after the divorce from Yoyok and the success and happiness of Ayna with her husband Afif.

\section{Suggestion}

Based on the results of research and discussion, several suggestions can be found in this study, namely:

1. Indonesian language teacher, can be used as a learning support source for writing novels. The results of research on the narrative style of time, both in terms of duration, order, and frequency in the Bidadari Bermata Bening novel by Habiburrahman El Shirazy can be one of the novel models given by the teacher to students when they are going to write a novel.

2. For readers, the Bidadari Bermata Bening novel by Habiburrahman El Shirazy can be used as a reading choice because it contains variations in time style in terms of duration, order, and frequency so as to provide an interesting effect and curiosity to read events from one event to another to the ending of the story. In addition, this novel in terms of telling gives a lesson about sincerity and hard work will have an impact on happiness.

3. For further research, providing new understanding and knowledge, especially in developing a narrative style theory of Indonesian litterateur. The next researcher in examining other narrative styles apart from the narrative style of time, the narrative style in terms of aspects of characterization, and the narrative style in terms of aspects of focalisation.

\section{References}

1. Aswidaningrum, R, dkk. (2017). Tumpang-Tindih Konflik dalam Novel Kambing dan Hujan Karya Mahfud Ikhwan (The Overlapping Conflicts in Mahfud Ikhwan's Kambing dan Hujan).Mozaik Humaniora, 17 (1), 149. https://e-journal.unair.ac.id. 
2. Barry, P. (2002). Beginning Theory: An Introduction to Literary and Cultural Theory. England: University Press.

3. Chatman, S. (1980). Story and Discourse Narrative Fiction and Film. London: Cornel University Press.

4. Creswell, J. (2007). Qualiitative Inquiry and Research Design. London: Sage.

5. Didipu, H. (2018). Struktur Naratif Novel Osakat Anak Asmat Karya Ani Sekarningsih (Perspektif Naratologi Gérard Genette). Aksara Jurnal Bahasa dan Sastra, 13(1), 15-27. http://jurnal.fkip.unila.ac.id/index.php/aksara.

6. Eriyanto. (2013). Analisis Naratif: Dasar-Dasar dan Penerapannya dalam Analisis Teks Berita Media. Jakarta: Kencana.

7. Eriyanto. (2017). Analisis Narartif. Jakarta: Kencana.

8. Gamble, N. \& Yates, S. (2002). Exploring Children's Literature: Teaching the Language and Reading of Fixtion. London: Paul Chapman Publishing.

9. Hartono. (2005). Tata, Durasi, dan Frekuensi dalam Novel Orang-Orang Proyek Karya Ahmad Tohari (Analisis Struktur Naratif). Litera, 4 (1), 54.

10. Herman, D. (2007). The Cambridge Companion to Narrative. New York: Cambridge University Press.

11. Herman, L. \& Vervaeck, B. (2005). Handbook af Narrative Analysis. USA: University of Nebraska Press.

12. Kustanto, L. (2015). Analisis Naratif: Kemiskinan dalam Program Reality TV "Pemberian Misterius" di Statiun SCTV. Rekam: Jurnal Fotografi, Televisi, dan Animasi 11(2), 114. Doi:10.24821/rekam.v11i2.1297.

13. Mihardja, R. (2012). Sastra Indonesia. Jakarta: Laskar Aska.

14. Noermanzah, N. N. (2017). Plot in a Collection of Short Stories "Sakinah Bersamamu" Works of Asma Nadia with Feminimism Analysis. Humanus: Jurnal Ilmiah Ilmu-ilmu Humaniora, 16(1), 27. doi:10.24036/jh.v16i1.7015 
15. Noermanzah, Wardhana, D.E.C., Friantary, H., Arsyad, S. (2019). Joko Widodo's Rhetorical Structure in the Presidential Speeches for Addressing Educational Problems. International Journal of Scientific and Technology Research, 8(10), 1795.

16. Nurgiyantoro, B. (2012). Teori Pengkajian Fiksi. Yogyakarta: Gadjah Mada University Press.

17. Shirazy, H. E. (2017). Bidadari Bermata Bening. Jakarta: Republik.

18. Sulaeman, A., Goziyah, Purawinangun, I.A., Noermanzah. (2020). Social Value in the Novel Hatta: Aku Datang karena Sejarah by Sergius Sutanto as Teaching Materials in Teaching Literature in Schools. International Journal of Scientific and Technology Research, 9(3). 611. http://www.ijstr.org/paper-references.php?ref=IJSTR-0320-32332

19. Thahar, H, E. (2008). Kiat Menulis Cerita Pendek. Bandung: Angkasa.

20. Todorov, T. (1985). Tata Sastra (terjemahan Okke K.S. Zaimar, dkk.). Jakarta: Djambatan.

21. Wellek \& Warren. (1976). Theory of Literature. USA: Penguin University Books.

22. Zakir, S.M. (2014). Karya dan Kekuasaan Pengarang: Pemikiran dan Gaya Naratif Mutakhir Anwar Ridhwan.Jurnal Melayu Jilid, 12(1), 73. 